Keywords

tumor immunology; tolerance; immune suppression; myeloid-derived suppressor cells; MDSC

\title{
1. Ray Owen
}

As a graduate student in Ray Owen's laboratory in the 1970's, one quickly became aware of having the privilege of training in the lab or a truly remarkable individual. Ray's groundbreaking studies demonstrating that twin cattle sharing a common placenta do not immunologically respond to their co-twin's genetically disparate red cell antigens established the concept of immunological tolerance [1], and set the framework for much of future immunology. Although I didn't realize it at the time, and many contemporary immunologists may not appreciate it now, Ray's work also profoundly impacted the field of tumor immunology, a research area in which he did not directly participate.

Corresponding Author: S. Ostrand-Rosenberg, Dept. of Biological Sciences, University of Maryland Baltimore County, 1000 Hilltop Circle, Baltimore, MD 21250; srosenbe @ umbc.edu; 410 455-22337 (voice); 410 455-3875 (FAX).

Publisher's Disclaimer: This is a PDF file of an unedited manuscript that has been accepted for publication. As a service to our customers we are providing this early version of the manuscript. The manuscript will undergo copyediting, typesetting, and review of the resulting proof before it is published in its final citable form. Please note that during the production process errors may be discovered which could affect the content, and all legal disclaimers that apply to the journal pertain. 


\section{Origins of cancer immunology/immunotherapy}

The concept that the immune system has the ability to surveil and destroy malignant cells is not new. Its roots originated in the late 1800's/early 1900's with the German pathologist Paul Ehrlich. In his "magic bullet" theory Ehrlich proposed that proteins targeting specific molecules on cancer cells could be used as a delivery mechanism for lethal payloads, and that in the absence of an immune response, cancers would be much more prevalent [2]. In the same era, the oncologist William Coley demonstrated that a small percentage of patients with advanced cancer experienced tumor regression following immunization with bacterial toxins [3]. Thus, the first consideration that the immune system could be exploited as a cancer therapeutic, and the first attempt at cancer immunotherapy occurred over 100 years ago. Not surprisingly these results were largely ignored by oncologists since Coley's treatment was accompanied by significant toxicity and only helped $\sim 10 \%$ of sarcoma patients, and Ehrlich's concept wasn't tested experimentally. However, this early work formed the basis for what became known as the "cancer immunosurveillance" theory. The forerunner of this theory was set out by Lewis Thomas [4], but it was Sir Macfarlane Burnet who coined the term "immunosurveillance" [5] and formulated the concept that the immune system eliminates abnormal and malignant cells before they form clinically detectable tumors [6]. The concept of immunosurveillance remained credible until the early 1970's when Stutman and colleagues demonstrated that both immunocompetent and nude ( $\mathrm{T}$ cell deficient) mice equally rejected transplanted tumors, supposedly indicating that the immune system played no role in tumor progression [7, 8]. Immunosurveillance made a partial recovery in the mid 1980's when it was realized that nude mice have both functional T cells and NK cells [9]. From the early 1970's to the early 1990's investigators in the field of tumor immunology were mostly ignored by mainstream immunologists and oncologists, although considerable progress was made in identifying tumor-associated antigens that served as immunological target moieties. Then, in 2002, Schreiber and colleagues published the first of a series of ground-breaking papers introducing the concept of "immunoediting" and demonstrating unequivocally that the repertoire of tumor cells is sculpted by the host's immune system [10]. These latter studies not only resurrected the concept that the immune system could eliminate tumor cells, but also set the stage for explaining why the immune system was not always effective in mediating tumor rejection. As demonstrated by Schreiber and colleagues, immunoediting involves multiple rounds of selecting for tumor cells that evade anti-tumor immunity, and includes selection by both anti-tumor and pro-tumor immune cells. Anti-tumor immune cells include a variety of cells (e.g. effector and helper $\mathrm{CD}^{+}$and $\mathrm{CD}^{+} \mathrm{T}$ cells, respectively, NK cells, anti-tumor macrophages, etc.); however, there are also immune cells that facilitate tumor progression by functionally inhibiting immune effector cells (e.g. T regulatory cells, pro-tumor macrophages, mast cells, myeloidderived suppressor cells). Therefore, the concept that the immune system can reject resident cancer cells is alive and well. However, it is also now obvious that immune-mediated tumor rejection is not simply a matter of activating a host's immune response since there are also multiple cellular and molecular mechanisms that suppress anti-tumor immunity. 


\section{Owen's discovery of tolerance and its impact on the field of tumor immunology}

Using the red blood cell reagents he and colleagues had developed, Owen discovered that genetically disparate fraternal cattle twins sharing a common placenta are tolerant to their co-twins' allogeneic red blood cells [1]. This was the first report of immunological tolerance, and Owen concluded that the tolerance was because the common placenta enabled the sharing of red blood cells during gestation, and therefore that tolerance was established during embryogenesis. This concept was formalized by Burnet [11] and experimentally confirmed by Medawar and colleagues [12]. Initially, the neonatally-induced tolerance appeared to be at odds with the concept of immunosurveillance because tumor cells were thought to be "self." However, as tumor antigens were discovered to be mutated selfproteins that arose during tumorigenesis [13], self-tolerance was no longer perceived as an issue. Owen's studies focused on neonatal tolerance; however, they also brought the general topic of tolerance to the forefront of immunology research. Subsequent studies have elegantly shown that tolerance can be induced centrally via negative selection in the thymus, as well as peripherally by a multitude of immune cells and secreted factors. When we speak of "tolerance to tumors" we are actually including a variety of mechanisms that prevent efficacy of anti-tumor immunity. These mechanisms include $\mathrm{T}$ regulatory cells that inhibit cytotoxic $\mathrm{T}$ cell function, tolerogenic antigen presenting cells, immune suppressive factors such as TGF $\beta$ and IL-10, as well as the more recently described myeloid-derived suppressor cells (MDSC). The following sections focus on MDSC, a potently immune suppressive cell population that is elevated in most cancer patients and is a significant obstacle to both induced and natural anti-tumor immunity. When my lab started working in this area circa 2000 , I didn't realize we were returning to my "roots" and working on issues of immune tolerance.

\section{MDSC are profoundly immune suppressive/tolerogenic cells that are present in virtually all cancer patients}

Immune suppressive so-called "natural suppressors" were originally identified in tumor-free mice [14], and were subsequently also found in tumor-bearing mice [15]. They were considered unusual cells because they were neither MHC-restricted nor antigen-specific and were of myeloid, rather than lymphoid, origin. A decade later, comparable cells were identified in the circulation of head and neck cancer patients [16-18], non-small cell lung and breast cancer patients [19], and mice with tumors [20, 21]. Biochemical studies demonstrated that the cells' suppressive potency was the result of their expression of reactive oxygen species (ROS) ${ }^{1}$ [22]. Because of their suppressive function and myeloid origin, the cells were named "myeloid-derived suppressor cells" [23]. Subsequent clinical studies have revealed that MDSC accumulate within the blood of virtually all cancer

\footnotetext{
${ }^{1}$ Abbreviations used in this article: Arg1, arginase 1; Bregs, regulatory B cells; $\mathrm{COX}_{2}$, cyclooxygenase 2; Gr-MDSC, granulocytic MDSC; HMGB1, high mobility group box protein 1; iNOS or NOS2, inducible nitric oxide synthase; L-arg, L-arginine; MDSC, myeloid-derived suppressor cells; MO-MDSC, monocytic MDSC; NO, nitric oxide; NOX2, NADPH oxidase; NSAIDS, non-steroidal anti-inflammatory drugs; PMN-MDSC, polymorphonuclear MDSC; PGE2, prostaglandin E2; ROS, reactive oxygen species; TAM(s), tumor-associated macrophage(s); TME, tumor microenvironment; Tregs, Regulatory T cells
} 
patients, and parallel studies in mice have demonstrated that MDSC arise in the bone marrow and traffic via the circulatory system on their way to homing in solid tumors [24].

MDSC also accumulate in non-cancerous diseases including infectious conditions such as toxoplasmosis [25], candidiasis [26], and leishmaniasis [27]. They are also elevated in HIVinfected patients [28], in individuals with Staphylococcus aureus biofilms [29], under conditions of sepsis [30,31], and in individuals undergoing stress [32, 33]. Elevated levels of MDSC are also associated with normal aging [34, 35].

Most of the information about MDSC function has been derived from studies in which MDSC develop in response to malignancy so the following sections are focused on tumorinduced MDSC.

\section{MDSC share markers with other myeloid cells and are distinguished by their unique suppressive properties}

MDSC are a mixture of cells of myeloid origin that have been halted in various stages of differentiation. Since the maturation of myeloid lineage cells is a continuum of differentiation stages, and the different stages can be identified by cell surface proteins, MDSC can express a variety of plasma membrane markers. However, there are two basic categories of mature MDSC: monocytic MDSC (MO-MDSC) and granulocytic or polymorphonuclear MDSC (Gr-MDSC or PMN-MDSC). MO-MDSC are mononuclear and Gr-MDSC are polymorphonuclear. In the mouse, all MDSC express the granulocytic marker Gr1 and the monocyte/macrophage marker CD11b. Gr1 includes both Ly6G and Ly6C and MO-MDSC are CD11b ${ }^{+} \mathrm{Ly}_{6} \mathrm{~L}^{+} \mathrm{LG}^{-/ \mathrm{low}}$, while Gr-MDSC or CD11b ${ }^{+} \mathrm{Ly}^{-} \mathrm{C}^{-} \mathrm{Ly}_{6 \mathrm{G}}{ }^{+}$. Other markers have also been attributed to mouse MDSC, including F4/80, IL-4Ra (CD124), CSF-1 (CD115), and CCR2 [36-40]. Expression of these latter markers varies from individual to individual since their expression is regulated by tumor secreted factors which can differ from tumor-to-tumor and within different stages of tumor progression.

The same two subclasses of MDSC are also present in patients with cancer. Human MOMDSC are phenotypically $\mathrm{CD} 11 \mathrm{~b}^{+} \mathrm{CD} 14^{+} \mathrm{CD} 15^{-} \mathrm{IL}-4 \mathrm{Ra}^{+} \mathrm{MHC}^{-/ \mathrm{low}}$ and Gr-MDSC are

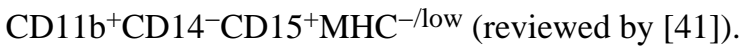

Since these markers are also expressed by other cell types, the defining characteristics of MDSC are their suppressive and pro-tumor functions which impact both innate and adaptive immunity, as well as non-immune mechanisms. They inhibit innate anti-tumor immunity by polarizing macrophages towards a tumor-promoting phenotype [42-45], and by blocking the cytotoxic activity of NK cells and NK cell production of IFN $\gamma$ [46-48]. They suppress adaptive anti-tumor immunity by preventing $\mathrm{T}$ cell activation, inhibiting the function of activated $\mathrm{T}$ cells, and by perturbing $\mathrm{T}$ cell trafficking (reviewed in [49]. In addition to their immunological effects, MDSC also facilitate tumor growth by supporting neoangiogenesis and tumor cell invasion and metastasis through their production of matrix metalloproteinase-9 [50, 51], VEGF [52], and MCP-1 [53], and they may enhance the epithelial-mesenchyme transition by their production of TGF $\beta$ [54]. 


\section{MDSC tolerize the host through a variety of immune suppressive mechanisms}

MDSC mediate tolerance through multiple mechanisms that are active in the periphery. They produce arginase 1 (Arg1) which deprives $\mathrm{T}$ cells of the essential amino acid Larginine (L-arg) and thereby causes a down-regulation of the CD3-associated $\zeta$ chain and loss of ability to signal through the TcR and down-stream signal transduction events that result in T cell proliferation $[55,56]$. MDSC also sequester cystine/cysteine which T cells cannot de novo synthesize since they lack the enzyme cystathionase which is needed to convert intracellular methionine to cysteine [57]. Their production of inducible nitric oxide synthase (iNOS or NOS2) degrades L-arg to nitric oxide (NO) which, in turn, prevents the activation of transcription factors needed to stabilize IL-2 mRNA and IL-2 receptor expression [58].

In addition to the mechanisms involving amino acid deprivation, MDSC also tolerize/ suppress by their production of reactive oxygen species (ROS). STAT3 phosphorylation in MDSC activates two subunits of NADPH oxidase (NOX2) (p47 phox and gp91 ${ }^{\text {phox }}$ ) which increases the intracellular levels of ROS including nitric oxide (NO) and superoxide $\left(\mathrm{O}_{2-}\right)$ $[59,60]$. $\mathrm{NO}$ and $\mathrm{O}_{2-}$ subsequently form peroxynitrite $\left(\mathrm{ONOO}^{-}\right)$which is a potent inhibitor of $\mathrm{T}$ cell activation and function because it nitrates/nitrosylates the TcR [61] and MHC class I molecules [62], thereby altering TcR and MHC structure and preventing T cell-target cell binding.

Efficiency of these suppressive mechanisms requires close proximity of MDSC and their target cells since many of the effector molecules are soluble proteins or factors such as enzymes and ROS. Exosomes released from MDSC as well as intact MDSC can mediate many MDSC suppressive functions. For example, MDSC-derived exosomes up-regulate macrophage production of IL-10 and chemoattract MDSC through their content of proinflammatory mediators including S100A8/A9 [63] and high mobility group box protein 1 (HMGB1) (Ostrand-Rosenberg, Clements, and Fenselau, unpublished). Many proteins in MDSC exosomes are ubiquitinated [64], including S100A8/A9 and HMGB1, but it remains to be demonstrated if the ubiquitinated molecules are the active forms.

Collectively, these inhibitory mechanisms establish a state of tolerance in individuals with cancer and prevent a naturally arising immune response from eliminating the tumor and are a significant obstacle to therapies aimed at activating a patient's immune system.

\section{MDSC amplify tolerance by cross-talk with other cells in the tumor microenvironment (TME)}

Solid tumors include a plethora of non-malignant host cells in addition to cancer cells, including tumor-associated macrophages (TAMs), regulatory T cells (Tregs), plasmacytoid dendritic cells, mast cells, cancer-associated fibroblasts (CAFs), as well as neutrophils, B and $\mathrm{T}$ lymphocytes, and other myeloid cells (reviewed in [65]). In addition to their direct effects on tumor progression, MDSC also regulate tumor growth by impacting these other cells in the TME. The best characterized effects are the reciprocal effects between MDSC 
and macrophages. Macrophages display a continuum of phenotypes ranging from tumoricidal (M1-like) to tumor-promoting (M2-like) (reviewed in [66]). MDSC production of IL-10 down-regulates TAM production of IL-6, IL-12, and TNFa, thereby polarizing TAMs towards a tumor-promoting phenotype [43, 44, 67]. IL-10 produced by MDSC also impairs the ability of macrophages to function as antigen presenting cells by downregulating macrophage expression of MHC II molecules [45]. Macrophages, in turn, enhance MDSC production of IL-10, providing a feedback mechanism for sustaining tumorpromoting TAMs. MDSC also drive the differentiation of immune suppressive T regulatory cells (Tregs). The induction of mouse Tregs is dependent on IL-10 and is regulated by Arg 1 , both of which are provided by MDSC $[37,68]$.

The accumulation and suppressive potency of MDSC are also enhanced by other cells in the TME. In a pancreas system, CAFs produce GM-CSF and IL-6 which drive the differentiation of MDSC by activating STAT3 [69]. In at least some cancers tumor-induced regulatory B cells (Bregs) are needed to educate and maximize MDSC suppressive potency through a TGF $\beta$ receptor-dependent process [70]. Likewise, tumor-induced NKT cells increase MDSC function by producing IL-13 which drives the accumulation of MDSC producing immune suppressive TGF $\beta$ [71]. Mast cells also contribute to MDSC function [72] and do so through a process involving IFN $\gamma$, NO, and CD40-CD40L cross-talk [73].

Collectively, these findings demonstrate that the TME is a complex milieu of cells and that the effects of the TME on MDSC and vice-versa are likely to vary from tumor-to-tumor and individual-to-individual depending on the specific populations of resident non-malignant cells.

\section{Inflammation is a dominant driving force for the accumulation and function of MDSC}

As described in section 7, non-malignant cells exacerbate the accumulation and suppressive potency of MDSC. However, tumor cells also drive MDSC levels and function, and the specific effector molecules are predominantly pro-inflammatory factors [74]. Early studies identified VEGF, which also drives angiogenesis, as an inducer of MDSC [75, 76]. Many of the factors that drive myelopoiesis induce accumulation of MDSC, an observation that is not surprising since MDSC are aberrantly differentiated cells of the myeloid lineage. Specifically, GM-CSF [77-79] and G-CSF [80] both induce MO-MDSC and Gr-MDSC

Studies identifying pro-inflammatory mediators as inducers of MDSC led to the concept that inflammation facilitates tumor progression by inducing MDSC which establish an immune suppressive environment that deters anti-tumor immunity [74]. For example, IL-1 $\beta$ and IL-6, which are produced by many different types of tumor cells, are potent inducers of MDSC $[81,82]$. Prostaglandin $\mathrm{E}_{2}\left(\mathrm{PGE}_{2}\right)$ and cyclooxygenase $2\left(\mathrm{COX}_{2}\right)$ are produced by numerous mouse and human tumors, are commonly found in the TME, and drive MDSC differentiation and suppressive activity [83-86]. The concept that inflammation drives cancer progression through the induction of MDSC is supported by multiple observations demonstrating that non-steroidal-anti-inflammatory drugs (NSAIDS), antibodies to $\mathrm{COX}_{2}$ or prostaglandin $\mathrm{E} 2\left(\mathrm{PGE}_{2}\right)$, or genetic deficiencies in cognate receptors reduce the risk of 
cancer while reducing MDSC levels [83, 87-90]. Support for the role of prostaglandins in promoting MDSC also comes from in vitro studies in which MDSC were induced from bone marrow progenitor cells. In this experimental setting, $\mathrm{COX}_{2}, \mathrm{PGE}_{2}$, or NSAIDS prevented the in vitro differentiation of both human and mouse MDSC, while inclusion of $\mathrm{PGE}_{2}$ in the cultures enhanced the differentiation of MDSC [83, 85, 86, 91].

S100A8/A9 [39, 92] and HMGB1 [42] also enhance MDSC development and function. Both of these pro-inflammatory mediators are ubiquitously present in the TME. S100A8/A9 is secreted by a variety of myeloid cells including MDSC and HMGB1 is released by both viable and dying cells. Both molecules not only increase MDSC suppressive potency but are also chemoattractants for MDSC and are present in MDSC-released exosomes [63], (Ostrand-Rosenberg, Fenselau, and Clements, unpublished). Serum levels of MDSC, S100A8/A9 and HMGB1 were recently identified as negative biomarkers for successful treatment of melanoma patients with the anti-CTLA4 mAb Ipilimumab [93], confirming the negative impact of inflammation-induced MDSC on anti-tumor immunity.

\section{Therapies that universally neutralize MDSC are needed}

MDSC differentiate from progenitor cells in the bone marrow and then enter the blood stream. In individuals with solid tumors, they are then chemoattracted to the site of tumor. Their half-life in vitro is approximately 1-2 days and in the blood is less than 24 hrs [94]. Their survival time within solid tumors is not known. Despite their relatively short half-life, MDSC can accumulate to high levels in cancer patients due to their rapid generation in bone marrow. Several mechanisms have been identified that regulate MDSC survival. Inflammation, and particularly IL-1 $\beta$ [81, 82] and HMGB1 [95] not only drives MDSC accumulation but also extends their half-life. Mechanistically, increased survival has been attributed to miRNA-494 through its ability to activate the AKT pathway [96], and to activation of the transcription factor Nrf2, which up-regulates anti-oxidant genes and protects MDSC from ROS [97]. Survival of MDSC is decreased by activated FasL ${ }^{+}$T cells which induce apoptosis of $\mathrm{Fas}^{+}$MDSC $[98,99]$.

Given the widespread presence and potent immune suppressive ability of MDSC in cancer patients, much work has focused on identifying agents that will eliminate or neutralize the cells. Many drugs have been identified; however, to date, none are universally effective against all MDSC. See [100-102] for recent reviews of strategies and drugs that target MDSC.

\section{MDSC may be useful for inducing tolerance in pathological conditions where immunity causes disease}

Owen's studies identified tolerance as a mechanism that protects against unwanted immune responses by inducing tolerance to benign cells that were normally present in the individual. In individuals with cancer, MDSC are also tolerogenic; however, the tolerance is not beneficial and instead prevents the host from rejecting cells that should be eliminated by the immune system. However, there are disease situations in which MDSC could be beneficial, and recent studies are exploring the use of MDSC to treat pathological situations in which 
unwanted immune responses occur. For example, MDSC have been tested in several mouse models of autoimmunity and have had varying success in reducing disease. In murine experimental autoimmune encephalomyelitis adoptive transfer of MDSC decreased demyelination and delayed disease progression [103]. In the same study it was observed that the blood of patients with active multiple sclerosis contained elevated levels of MDSC that suppressed the activation of $\mathrm{CD}^{+}$autologous $\mathrm{T}$ cells. Co-transplantation of MDSC sustained the survival of transplanted islet allografts and was fully dependent on MDSC expression of $\mathrm{B} 7-\mathrm{H} 1^{+}\left(\mathrm{PD}-\mathrm{L}^{+}\right)$, suggesting that MDSC may be useful for the treatment of diabetes [104]. In a mouse system of collagen-induced arthritis, adoptive transfer of MDSC inhibited pro-inflammatory responses of $\mathrm{CD}^{+} \mathrm{T}$ cells and reduced severity of disease [105]. Adoptive transfer of MDSC also decreased intestinal inflammation, and levels of IFN $\gamma$, TNF, and IL-17 in mice with experimental colitis [106]. MDSC have also shown therapeutic efficacy in a mouse model of experimental autoimmune myasthenia gravis that involves autoreactive B and T cells. In this setting, adoptive transfer of MDSC induced by hepatic stellate cells reversed disease progression by inhibiting acetyl choline receptor-specific immune responses without impacting immunity to non-disease target molecules [107]. MDSC generated in vitro from bone marrow progenitor cells have also been used in mouse models to treat graft-vs-host lethality [108], and to induce Tregs to prevent the onset of type 1 diabetes [109]. In both mice and patients exacerbation of allergy-induced asthma is associated with diminished immune suppressive function of Gr-MDSC [110]. Recent studies also show a correlation between reduced levels of MDSC and miscarriage [111, 112], suggesting that MDSC may also be implicated in normal pregnancies. Therefore, MDSC may play a critical role in combating autoimmune and allergic reactions and have the potential to be exploited as therapeutic agents for multiple diseases involving harmful immune responses.

\section{Conclusions}

For the past $60+$ years tolerance has served as a central concept that has impacted much of the progress in immunology research. Early studies focused on tolerance to self molecules, and as the field of immunology has progressed it has become apparent that the concept is also integral to non-self, mutated self, and danger signals. Tolerance as initially characterized by Owen was defined in terms of its beneficial consequences in preventing autoreactivity. However, tolerance can also be detrimental such as in cancer when immune suppression-induced tolerance protects malignant cells against potentially beneficial antitumor immunity, or when neonates have reduced immunocompetence due to the presence of immune-suppressive CD71+ erythroid cells[113]. Obviously, the work of very many investigators throughout the world over the past 60+ years has contributed to current understanding of tolerance. However, it is clear that Ray Owen's studies provided a starting point and laid the foundations for much of the knowledge that has facilitated the advancement of basic immunology and its applications which have led to significant clinical developments. 


\section{Acknowledgments}

Original work described in this article was supported by grants from the NIH (RO1CA115880, RO1CA84232, and RO1GM021248).

\section{References}

1. Owen RD. Immunogenetic Consequences of Vascular Anastomoses between Bovine Twins. Science. 1945; 102:400-401. [PubMed: 17755278]

2. Ehrlich P. Uber den jetzigen Stand der Karzinomforschung. Ned Tijdschr Geneeskd. 1909; 5:2730290.

3. Coley W. The treatment of malignant tumors by repeated inoculations of erysipelas: with a report of ten original cases. Am J Med Sci. 1893; 105:487-511.

4. Thomas, L. Discussion of celular and humoral aspects of the hypersensitivity states. In: Lawrence, H., editor. Cellular and Humoral Aspects of Hypersensitivity. Hoeber-Harper; New York: 1959. p. 529-532.

5. Burnet M. Immunological Factors in the Process of Carcinogenesis. Br Med Bull. 1964; 20:154158. [PubMed: 14168097]

6. Burnet FM. Immunological aspects of malignant disease. Lancet. 1967; 1:1171-1174. [PubMed: 4165129]

7. Stutman O. Immunodepression and malignancy. Adv Cancer Res. 1975; 22:261-422. [PubMed: 766581]

8. Stutman O. Chemical carcinogenesis in nude mice: comparison between nude mice from homozygous matings and heterozygous matings and effect of age and carcinogen dose. J Natl Cancer Inst. 1979; 62:353-358. [PubMed: 283266]

9. Maleckar JR, Sherman LA. The composition of the T cell receptor repertoire in nude mice. J Immunol. 1987; 138:3873-3876. [PubMed: 2953792]

10. Shankaran V, Ikeda H, Bruce AT, White JM, Swanson PE, Old LJ, Schreiber RD. IFNgamma and lymphocytes prevent primary tumour development and shape tumour immunogenicity. Nature. 2001; 410:1107-1111. [PubMed: 11323675]

11. Burnet, FM.; Fenner, F. The production of antibodies. Mcmillan; London: 1949.

12. Billingham RE, Brent L, Medawar PB. Actively acquired tolerance of foreign cells. Nature. 1953; 172:603-606. [PubMed: 13099277]

13. Fenton RG, Longo DL. Genetic instability and tumor cell variation: implications for immunotherapy. J Natl Cancer Inst. 1995; 87:241-243. [PubMed: 7707413]

14. Strober S. Natural suppressor (NS) cells, neonatal tolerance, and total lymphoid irradiation: exploring obscure relationships. Annu Rev Immunol. 1984; 2:219-237. [PubMed: 6152690]

15. Young MR, Young ME, Wright MA. Myelopoiesis-associated suppressor-cell activity in mice with Lewis lung carcinoma tumors: interferon-gamma plus tumor necrosis factor-alpha synergistically reduce suppressor cell activity. Int J Cancer. 1990; 46:245-250. [PubMed: 2143498]

16. Garrity T, Pandit R, Wright MA, Benefield J, Keni S, Young MR. Increased presence of CD34+ cells in the peripheral blood of head and neck cancer patients and their differentiation into dendritic cells. Int J Cancer. 1997; 73:663-669. [PubMed: 9398043]

17. Young MR, Wright MA, Lozano Y, Matthews JP, Benefield J, Prechel MM. Mechanisms of immune suppression in patients with head and neck cancer: influence on the immune infiltrate of the cancer. Int J Cancer. 1996; 67:333-338. [PubMed: 8707405]

18. Young MR, Wright MA, Lozano Y, Prechel MM, Benefield J, Leonetti JP, Collins SL, Petruzzelli GJ. Increased recurrence and metastasis in patients whose primary head and neck squamous cell carcinomas secreted granulocyte-macrophage colony-stimulating factor and contained CD34+ natural suppressor cells. Int J Cancer. 1997; 74:69-74. [PubMed: 9036872]

19. Almand B, Clark JI, Nikitina E, van Beynen J, English NR, Knight SC, Carbone DP, Gabrilovich DI. Increased production of immature myeloid cells in cancer patients: a mechanism of immunosuppression in cancer. J Immunol. 2001; 166:678-689. [PubMed: 11123353] 
20. Bronte V, Wang M, Overwijk WW, Surman DR, Pericle F, Rosenberg SA, Restifo NP. Apoptotic death of CD8+ T lymphocytes after immunization: induction of a suppressive population of Mac-1+/Gr-1+ cells. J Immunol. 1998; 161:5313-5320. [PubMed: 9820504]

21. Gabrilovich DI, Velders MP, Sotomayor EM, Kast WM. Mechanism of immune dysfunction in cancer mediated by immature Gr-1+ myeloid cells. J Immunol. 2001; 166:5398-5406. [PubMed: 11313376]

22. Schmielau J, Finn OJ. Activated granulocytes and granulocyte-derived hydrogen peroxide are the underlying mechanism of suppression of t-cell function in advanced cancer patients. Cancer Res. 2001; 61:4756-4760. [PubMed: 11406548]

23. Gabrilovich DI, Bronte V, Chen SH, Colombo MP, Ochoa A, Ostrand-Rosenberg S, Schreiber H. The terminology issue for myeloid-derived suppressor cells. Cancer Res. 2007; 67:425. author reply 426. [PubMed: 17210725]

24. Gabrilovich DI, Nagaraj S. Myeloid-derived suppressor cells as regulators of the immune system. Nat Rev Immunol. 2009; 9:162-174. [PubMed: 19197294]

25. Voisin MB, Buzoni-Gatel D, Bout D, Velge-Roussel F. Both expansion of regulatory GR1+ $\mathrm{CD} 11 \mathrm{~b}+$ myeloid cells and anergy of T lymphocytes participate in hyporesponsiveness of the lung-associated immune system during acute toxoplasmosis. Infection \& Immunity. 2004; 72:5487-5492. [PubMed: 15322051]

26. Mencacci A, Montagnoli C, Bacci A, Cenci E, Pitzurra L, Spreca A, Kopf M, Sharpe AH, Romani L. CD80+Gr-1+ myeloid cells inhibit development of antifungal Th1 immunity in mice with candidiasis. J Immunol. 2002; 169:3180-3190. [PubMed: 12218136]

27. Sunderkotter C, Nikolic T, Dillon MJ, Van Rooijen N, Stehling M, Drevets DA, Leenen PJ. Subpopulations of mouse blood monocytes differ in maturation stage and inflammatory response. J Immunol. 2004; 172:4410-4417. [PubMed: 15034056]

28. Garg A, Spector SA. HIV type 1 gp120-induced expansion of myeloid derived suppressor cells is dependent on interleukin 6 and suppresses immunity. J Infect Dis. 2014; 209:441-451. [PubMed: 23999600]

29. Heim CE, Vidlak D, Scherr TD, Kozel JA, Holzapfel M, Muirhead DE, Kielian T. Myeloidderived suppressor cells contribute to Staphylococcus aureus orthopedic biofilm infection. J Immunol. 2014; 192:3778-3792. [PubMed: 24646737]

30. Delano MJ, Scumpia PO, Weinstein JS, Coco D, Nagaraj S, Kelly-Scumpia KM, O’Malley KA, Wynn JL, Antonenko S, Al-Quran SZ, Swan R, Chung CS, Atkinson MA, Ramphal R, Gabrilovich DI, Reeves WH, Ayala A, Phillips J, Laface D, Heyworth PG, Clare-Salzler M, Moldawer LL. MyD88-dependent expansion of an immature GR-1(+)CD11b(+) population induces T cell suppression and Th2 polarization in sepsis. J Exp Med. 2007; 204:1463-1474. [PubMed: 17548519]

31. Sander LE, Sackett SD, Dierssen U, Beraza N, Linke RP, Muller M, Blander JM, Tacke F, Trautwein C. Hepatic acute-phase proteins control innate immune responses during infection by promoting myeloid-derived suppressor cell function. J Exp Med. 2010; 207:1453-1464. [PubMed: 20530204]

32. Makarenkova VP, Bansal V, Matta BM, Perez LA, Ochoa JB. CD11b+/Gr-1+ myeloid suppressor cells cause T cell dysfunction after traumatic stress. J Immunol. 2006; 176:2085-2094. [PubMed: 16455964]

33. Mundy-Bosse BL, Thornton LM, Yang HC, Andersen BL, Carson WE. Psychological stress is associated with altered levels of myeloid-derived suppressor cells in breast cancer patients. Cell Immunol. 2011; 270:80-87. [PubMed: 21600570]

34. Grizzle WE, Xu X, Zhang S, Stockard CR, Liu C, Yu S, Wang J, Mountz JD, Zhang HG. Agerelated increase of tumor susceptibility is associated with myeloid-derived suppressor cell mediated suppression of T cell cytotoxicity in recombinant inbred BXD12 mice. Mech Ageing Dev. 2007; 128:672-680. [PubMed: 18036633]

35. Verschoor CP, Johnstone J, Millar J, Dorrington MG, Habibagahi M, Lelic A, Loeb M, Bramson JL, Bowdish DM. Blood CD33(+)HLA-DR(-) myeloid-derived suppressor cells are increased with age and a history of cancer. J Leukoc Biol. 2013; 93:633-637. [PubMed: 23341539] 
36. Gallina G, Dolcetti L, Serafini P, De Santo C, Marigo I, Colombo MP, Basso G, Brombacher F, Borrello I, Zanovello P, Bicciato S, Bronte V. Tumors induce a subset of inflammatory monocytes with immunosuppressive activity on CD8+ T cells. J Clin Invest. 2006; 116:2777-2790. [PubMed: 17016559]

37. Huang B, Pan PY, Li Q, Sato AI, Levy DE, Bromberg J, Divino CM, Chen SH. Gr-1+CD115+ Immature Myeloid Suppressor Cells Mediate the Development of Tumor-Induced T Regulatory Cells and T-Cell Anergy in Tumor-Bearing Host. Cancer Res. 2006; 66:1123-1131. [PubMed: 16424049]

38. Movahedi K, Guilliams M, Van den Bossche J, Van den Bergh R, Gysemans C, Beschin A, De Baetselier P, Van Ginderachter JA. Identification of discrete tumor-induced myeloid-derived suppressor cell subpopulations with distinct T cell-suppressive activity. Blood. 2008; 111:42334244. [PubMed: 18272812]

39. Sinha P, Okoro C, Foell D, Freeze HH, Ostrand-Rosenberg S, Srikrishna G. Proinflammatory S100 proteins regulate the accumulation of myeloid-derived suppressor cells. J Immunol. 2008; 181:4666-4675. [PubMed: 18802069]

40. Youn JI, Nagaraj S, Collazo M, Gabrilovich DI. Subsets of myeloid-derived suppressor cells in tumor-bearing mice. J Immunol. 2008; 181:5791-5802. [PubMed: 18832739]

41. Peranzoni E, Zilio S, Marigo I, Dolcetti L, Zanovello P, Mandruzzato S, Bronte V. Myeloidderived suppressor cell heterogeneity and subset definition. Curr Opin Immunol. 2010; 22:238244. [PubMed: 20171075]

42. Parker K, Sinha P, Horn LA, Clements VK, Yang HC, Li J, Tracey KJ, Ostrand-Rosenberg S. High mobility group box protein 1 enhances immune suppression by facilitating the differentiation and suppressive activity of myeloid-derived suppressor cells. Cancer Res. 2014

43. Sinha P, Clements VK, Bunt SK, Albelda SM, Ostrand-Rosenberg S. Cross-talk between myeloidderived suppressor cells and macrophages subverts tumor immunity toward a type 2 response. $\mathrm{J}$ Immunol. 2007; 179:977-983. [PubMed: 17617589]

44. Beury DW, Parker KH, Nyandjo M, Sinha P, Carter KA, Ostrand-Rosenberg S. Cross-talk among myeloid-derived suppressor cells, macrophages, and tumor cells impacts the inflammatory milieu of solid tumors. J Leukoc Biol. 2014; 96:1109-1118. [PubMed: 25170116]

45. Ostrand-Rosenberg S, Sinha P, Beury DW, Clements VK. Cross-talk between myeloid-derived suppressor cells (MDSC), macrophages, and dendritic cells enhances tumor-induced immune suppression. Semin Cancer Biol. 2012

46. Li H, Han Y, Guo Q, Zhang M, Cao X. Cancer-expanded myeloid-derived suppressor cells induce anergy of NK cells through membrane-bound TGF-beta 1. J Immunol. 2009; 182:240-249. [PubMed: 19109155]

47. Liu C, Yu S, Kappes J, Wang J, Grizzle WE, Zinn KR, Zhang HG. Expansion of spleen myeloid suppressor cells represses NK cell cytotoxicity in tumor-bearing host. Blood. 2007; 109:43364342. [PubMed: 17244679]

48. Suzuki E, Kapoor V, Jassar AS, Kaiser LR, Albelda SM. Gemcitabine selectively eliminates splenic Gr-1+/CD11b+ myeloid suppressor cells in tumor-bearing animals and enhances antitumor immune activity. Clin Cancer Res. 2005; 11:6713-6721. [PubMed: 16166452]

49. Ostrand-Rosenberg, S. Myeloid-derived suppressor cells. In: Ratcliffe, M., editor. Encyclopedia of Immunobiology. Elsevier; 2016.

50. Yang L, DeBusk LM, Fukuda K, Fingleton B, Green-Jarvis B, Shyr Y, Matrisian LM, Carbone DP, Lin PC. Expansion of myeloid immune suppressor Gr+CD11b+ cells in tumor-bearing host directly promotes tumor angiogenesis. Cancer Cell. 2004; 6:409-421. [PubMed: 15488763]

51. Yang L, Huang J, Ren X, Gorska AE, Chytil A, Aakre M, Carbone DP, Matrisian LM, Richmond A, Lin PC, Moses HL. Abrogation of TGF beta signaling in mammary carcinomas recruits Gr-1+CD11b+ myeloid cells that promote metastasis. Cancer Cell. 2008; 13:23-35. [PubMed: 18167337]

52. Kujawski M, Kortylewski M, Lee H, Herrmann A, Kay H, Yu H. Stat3 mediates myeloid celldependent tumor angiogenesis in mice. J Clin Invest. 2008; 118:3367-3377. [PubMed: 18776941] 
53. Boelte KC, Gordy LE, Joyce S, Thompson MA, Yang L, Lin PC. Rgs2 mediates pro-angiogenic function of myeloid derived suppressor cells in the tumor microenvironment via upregulation of MCP-1. PLoS One. 2011; 6:e18534. [PubMed: 21494556]

54. Toh B, Wang X, Keeble J, Sim WJ, Khoo K, Wong WC, Kato M, Prevost-Blondel A, Thiery JP, Abastado JP. Mesenchymal transition and dissemination of cancer cells is driven by myeloidderived suppressor cells infiltrating the primary tumor. PLoS Biol. 2011; 9:e1001162. [PubMed: 21980263]

55. Ezernitchi AV, Vaknin I, Cohen-Daniel L, Levy O, Manaster E, Halabi A, Pikarsky E, Shapira L, Baniyash M. TCR zeta down-regulation under chronic inflammation is mediated by myeloid suppressor cells differentially distributed between various lymphatic organs. J Immunol. 2006; 177:4763-4772. [PubMed: 16982917]

56. Rodriguez PC, Quiceno DG, Zabaleta J, Ortiz B, Zea AH, Piazuelo MB, Delgado A, Correa P, Brayer J, Sotomayor EM, Antonia S, Ochoa JB, Ochoa AC. Arginase I production in the tumor microenvironment by mature myeloid cells inhibits T-cell receptor expression and antigen-specific T-cell responses. Cancer Res. 2004; 64:5839-5849. [PubMed: 15313928]

57. Srivastava MK, Sinha P, Clements VK, Rodriguez P, Ostrand-Rosenberg S. Myeloid-derived suppressor cells inhibit T-cell activation by depleting cystine and cysteine. Cancer Res. 2010; 70:68-77. [PubMed: 20028852]

58. Bronte V, Zanovello P. Regulation of immune responses by L-arginine metabolism. Nat Rev Immunol. 2005; 5:641-654. [PubMed: 16056256]

59. Corzo CA, Cotter MJ, Cheng P, Cheng F, Kusmartsev S, Sotomayor E, Padhya T, McCaffrey TV, McCaffrey JC, Gabrilovich DI. Mechanism regulating reactive oxygen species in tumor-induced myeloid-derived suppressor cells. J Immunol. 2009; 182:5693-5701. [PubMed: 19380816]

60. Nefedova Y, Huang M, Kusmartsev S, Bhattacharya R, Cheng P, Salup R, Jove R, Gabrilovich D. Hyperactivation of STAT3 is involved in abnormal differentiation of dendritic cells in cancer. $\mathrm{J}$ Immunol. 2004; 172:464-474. [PubMed: 14688356]

61. Nagaraj S, Gupta K, Pisarev V, Kinarsky L, Sherman S, Kang L, Herber DL, Schneck J, Gabrilovich DI. Altered recognition of antigen is a mechanism of CD8+ T cell tolerance in cancer. Nat Med. 2007; 13:828-835. [PubMed: 17603493]

62. Lu T, Ramakrishnan R, Altiok S, Youn JI, Cheng P, Celis E, Pisarev V, Sherman S, Sporn MB, Gabrilovich D. Tumor-infiltrating myeloid cells induce tumor cell resistance to cytotoxic $\mathrm{T}$ cells in mice. J Clin Invest. 2011; 121:4015-4029. [PubMed: 21911941]

63. Burke M, Choksawangkarn W, Edwards N, Ostrand-Rosenberg S, Fenselau C. Exosomes from myeloid-derived suppressor cells carry biologically active proteins. J Proteome Res. 2014; 13:836-843. [PubMed: 24295599]

64. Burke MC, Oei MS, Edwards NJ, Ostrand-Rosenberg S, Fenselau C. Ubiquitinated proteins in exosomes secreted by myeloid-derived suppressor cells. J Proteome Res. 2014; 13:5965-5972. [PubMed: 25285581]

65. Klemm F, Joyce JA. Microenvironmental regulation of therapeutic response in cancer. Trends Cell Biol. 2015; 25:198-213. [PubMed: 25540894]

66. Murray PJ, Allen JE, Biswas SK, Fisher EA, Gilroy DW, Goerdt S, Gordon S, Hamilton JA, Ivashkiv LB, Lawrence T, Locati M, Mantovani A, Martinez FO, Mege JL, Mosser DM, Natoli G, Saeij JP, Schultze JL, Shirey KA, Sica A, Suttles J, Udalova I, van Ginderachter JA, Vogel SN, Wynn TA. Macrophage activation and polarization: nomenclature and experimental guidelines. Immunity. 2014; 41:14-20. [PubMed: 25035950]

67. Bunt SK, Clements VK, Hanson EM, Sinha P, Ostrand-Rosenberg S. Inflammation enhances myeloid-derived suppressor cell cross-talk by signaling through Toll-like receptor 4. J Leukoc Biol. 2009; 85:996-1004. [PubMed: 19261929]

68. Serafini P, Mgebroff S, Noonan K, Borrello I. Myeloid-derived suppressor cells promote crosstolerance in B-cell lymphoma by expanding regulatory T cells. Cancer Res. 2008; 68:5439-5449. [PubMed: 18593947]

69. Mace TA, Ameen Z, Collins A, Wojcik S, Mair M, Young GS, Fuchs JR, Eubank TD, Frankel WL, Bekaii-Saab T, Bloomston M, Lesinski GB. Pancreatic cancer-associated stellate cells 
promote differentiation of myeloid-derived suppressor cells in a STAT3-dependent manner. Cancer Res. 2013; 73:3007-3018. [PubMed: 23514705]

70. Bodogai M, Moritoh K, Lee-Chang C, Hollander CM, Sherman-Baust CA, Wersto RP, Araki Y, Miyoshi I, Yang L, Trinchieri G, Biragyn A. Immunosuppressive and Prometastatic Functions of Myeloid-Derived Suppressive Cells Rely upon Education from Tumor-Associated B Cells. Cancer Res. 2015; 75:3456-3465. [PubMed: 26183924]

71. Terabe M, Matsui S, Park JM, Mamura M, Noben-Trauth N, Donaldson DD, Chen W, Wahl SM, Ledbetter S, Pratt B, Letterio JJ, Paul WE, Berzofsky JA. Transforming growth factor-beta production and myeloid cells are an effector mechanism through which CD1d-restricted T cells block cytotoxic T lymphocyte-mediated tumor immunosurveillance: abrogation prevents tumor recurrence. J Exp Med. 2003; 198:1741-1752. [PubMed: 14657224]

72. Saleem SJ, Martin RK, Morales JK, Sturgill JL, Gibb DR, Graham L, Bear HD, Manjili MH, Ryan JJ, Conrad DH. Cutting edge: mast cells critically augment myeloid-derived suppressor cell activity. J Immunol. 2012; 189:511-515. [PubMed: 22706087]

73. Danelli L, Frossi B, Gri G, Mion F, Guarnotta C, Bongiovanni L, Tripodo C, Mariuzzi L, Marzinotto S, Rigoni A, Blank U, Colombo MP, Pucillo CE. Mast cells boost myeloid-derived suppressor cell activity and contribute to the development of tumor-favoring microenvironment. Cancer Immunol Res. 2015; 3:85-95. [PubMed: 25351848]

74. Ostrand-Rosenberg S, Sinha P. Myeloid-derived suppressor cells: linking inflammation and cancer. J Immunol. 2009; 182:4499-4506. [PubMed: 19342621]

75. Gabrilovich DI, Chen HL, Girgis KR, Cunningham HT, Meny GM, Nadaf S, Kavanaugh D, Carbone DP. Production of vascular endothelial growth factor by human tumors inhibits the functional maturation of dendritic cells. Nat Med. 1996; 2:1096-1103. [PubMed: 8837607]

76. Young MR, Kolesiak K, Wright MA, Gabrilovich DI. Chemoattraction of femoral CD34+ progenitor cells by tumor-derived vascular endothelial cell growth factor. Clin Exp Metas. 1999; 17:881-888.

77. Dolcetti L, Peranzoni E, Ugel S, Marigo I, Fernandez Gomez A, Mesa C, Geilich M, Winkels G, Traggiai E, Casati A, Grassi F, Bronte V. Hierarchy of immunosuppressive strength among myeloid-derived suppressor cell subsets is determined by GM-CSF. Eur J Immunol. 2010; 40:2235. [PubMed: 19941314]

78. Morales JK, Kmieciak M, Knutson KL, Bear HD, Manjili MH. GM-CSF is one of the main breast tumor-derived soluble factors involved in the differentiation of CD11b-Gr1- bone marrow progenitor cells into myeloid-derived suppressor cells. Breast cancer research and treatment. 2010; 123:39-49. [PubMed: 19898981]

79. Serafini P, Carbley R, Noonan KA, Tan G, Bronte V, Borrello I. High-dose granulocytemacrophage colony-stimulating factor-producing vaccines impair the immune response through the recruitment of myeloid suppressor cells. Cancer Res. 2004; 64:6337-6343. [PubMed: 15342423]

80. Shojaei F, Wu X, Qu X, Kowanetz M, Yu L, Tan M, Meng YG, Ferrara N. G-CSF-initiated myeloid cell mobilization and angiogenesis mediate tumor refractoriness to anti-VEGF therapy in mouse models. Proc Natl Acad Sci U S A. 2009; 106:6742-6747. [PubMed: 19346489]

81. Bunt SK, Sinha P, Clements VK, Leips J, Ostrand-Rosenberg S. Inflammation Induces MyeloidDerived Suppressor Cells that Facilitate Tumor Progression. J Immunol. 2006; 176:284-290. [PubMed: 16365420]

82. Bunt SK, Yang L, Sinha P, Clements VK, Leips J, Ostrand-Rosenberg S. Reduced inflammation in the tumor microenvironment delays the accumulation of myeloid-derived suppressor cells and limits tumor progression. Cancer Res. 2007; 67:10019-10026. [PubMed: 17942936]

83. Sinha P, Clements VK, Fulton AM, Ostrand-Rosenberg S. Prostaglandin E2 promotes tumor progression by inducing myeloid-derived suppressor cells. Cancer Res. 2007; 67:4507-4513. [PubMed: 17483367]

84. Rodriguez PC, Hernandez CP, Quiceno D, Dubinett SM, Zabaleta J, Ochoa JB, Gilbert J, Ochoa AC. Arginase I in myeloid suppressor cells is induced by COX-2 in lung carcinoma. J Exp Med. 2005; 202:931-939. [PubMed: 16186186] 
85. Obermajer N, Muthuswamy R, Lesnock J, Edwards RP, Kalinski P. Positive feedback between PGE2 and COX2 redirects the differentiation of human dendritic cells toward stable myeloidderived suppressor cells. Blood. 2011; 118:5498-5505. [PubMed: 21972293]

86. Mao Y, Sarhan D, Steven A, Seliger B, Kiessling R, Lundqvist A. Inhibition of tumor-derived prostaglandin-E2 blocks the induction of myeloid-derived suppressor cells and recovers natural killer cell activity. Clin Cancer Res. 2014; 20:4096-4106. [PubMed: 24907113]

87. Harris RE, Beebe-Donk J, Alshafie GA. Reduction in the risk of human breast cancer by selective cyclooxygenase-2 (COX-2) inhibitors. BMC Cancer. 2006; 6:27. [PubMed: 16445867]

88. Meyer C, Sevko A, Ramacher M, Bazhin AV, Falk CS, Osen W, Borrello I, Kato M, Schadendorf D, Baniyash M, Umansky V. Chronic inflammation promotes myeloid-derived suppressor cell activation blocking antitumor immunity in transgenic mouse melanoma model. Proc Natl Acad Sci USA. 2011; 108:17111-17116. [PubMed: 21969559]

89. Talmadge JE, Hood KC, Zobel LC, Shafer LR, Coles M, Toth B. Chemoprevention by cyclooxygenase- 2 inhibition reduces immature myeloid suppressor cell expansion. Intern Immunopharm. 2007; 7:140-151.

90. Veltman JD, Lambers ME, van Nimwegen M, Hendriks RW, Hoogsteden HC, Aerts JG, Hegmans JP. COX-2 inhibition improves immunotherapy and is associated with decreased numbers of myeloid-derived suppressor cells in mesothelioma. Celecoxib influences MDSC function. BMC Cancer. 2010; 10:464. [PubMed: 20804550]

91. Eruslanov E, Daurkin I, Ortiz J, Vieweg J, Kusmartsev S. Pivotal Advance: Tumor-mediated induction of myeloid-derived suppressor cells and M2-polarized macrophages by altering intracellular PGE catabolism in myeloid cells. J Leukoc Biol. 2010; 88:839-848. [PubMed: 20587738]

92. Cheng P, Corzo CA, Luetteke N, Yu B, Nagaraj S, Bui MM, Ortiz M, Nacken W, Sorg C, Vogl T, Roth J, Gabrilovich DI. Inhibition of dendritic cell differentiation and accumulation of myeloidderived suppressor cells in cancer is regulated by S100A9 protein. J Exp Med. 2008; 205:22352249. [PubMed: 18809714]

93. Gebhardt C, Sevko A, Jiang H, Lichtenberger R, Reith M, Tarnanidis K, Holland-Letz T, Umansky L, Beckhove P, Sucker A, Schadendorf D, Utikal J, Umansky V. Myeloid cells and related chronic inflammatory factors as novel predictive markers in melanoma treatment with ipilimumab. Clin Cancer Res. 2015 epub ahead of print.

94. Sawanobori Y, Ueha S, Kurachi M, Shimaoka T, Talmadge JE, Abe J, Shono Y, Kitabatake M, Kakimi K, Mukaida N, Matsushima K. Chemokine-mediated rapid turnover of myeloid-derived suppressor cells in tumor-bearing mice. Blood. 2008; 111:5457-5466. [PubMed: 18375791]

95. Parker K, Ostrand-Rosenberg S. High Mobility Group Box Protein 1 Promotes the Survival of Myeloid-derived Suppressor Cells by Inducing Autophagy. 2015 submitted.

96. Liu Y, Lai L, Chen Q, Song Y, Xu S, Ma F, Wang X, Wang J, Yu H, Cao X, Wang Q. MicroRNA-494 is required for the accumulation and functions of tumor-expanded myeloidderived suppressor cells via targeting of PTEN. J Immunol. 2012; 188:5500-5510. [PubMed: 22544933]

97. Beury D, Carter KA, Nelson C, Nyandjo M, Fitzgerald P, Sinha P, Majeed A, Wali N, OstrandRosenberg S. Myeloid-derived suppressor cell survival and function are regulated by the transcription factor Nrf2. 2015 submitted.

98. Chornoguz O, Grmai L, Sinha P, Artemenko KA, Zubarev RA, Ostrand-Rosenberg S. Proteomic pathway analysis reveals inflammation increases myeloid-derived suppressor cell resistance to apoptosis. Molecular \& cellular proteomics: MCP. 2011; 10:M110 002980. [PubMed: 21191032]

99. Sinha P, Chornoguz O, Clements VK, Artemenko KA, Zubarev RA, Ostrand-Rosenberg S. Myeloid-derived suppressor cells express the death receptor Fas and apoptose in response to $\mathrm{T}$ cell-expressed FasL. Blood. 2011; 117:5381-5390. [PubMed: 21450901]

100. Parker KH, Beury DW, Ostrand-Rosenberg S. Myeloid-Derived Suppressor Cells: Critical Cells Driving Immune Suppression in the Tumor Microenvironment. Adv Cancer Res. 2015; 128:95139. [PubMed: 26216631] 
101. Filipazzi P, Huber V, Rivoltini L. Phenotype, function and clinical implications of myeloidderived suppressor cells in cancer patients. Cancer Immunol Immunother. 2012; 61:255-263. [PubMed: 22120756]

102. Montero AJ, Diaz-Montero CM, Kyriakopoulos CE, Bronte V, Mandruzzato S. Myeloid-derived Suppressor Cells in Cancer Patients: A Clinical Perspective. J Immunother. 2012; 35:107-115. [PubMed: 22306898]

103. Ioannou M, Alissafi T, Lazaridis I, Deraos G, Matsoukas J, Gravanis A, Mastorodemos V, Plaitakis A, Sharpe A, Boumpas D, Verginis P. Crucial role of granulocytic myeloid-derived suppressor cells in the regulation of central nervous system autoimmune disease. J Immunol. 2012; 188:1136-1146. [PubMed: 22210912]

104. Chou HS, Hsieh CC, Charles R, Wang L, Wagner T, Fung JJ, Qian S, Lu LL. Myeloid-derived suppressor cells protect islet transplants by b7-h1 mediated enhancement of T regulatory cells. Transplantation. 2012; 93:272-282. [PubMed: 22179405]

105. Fujii W, Ashihara E, Hirai H, Nagahara H, Kajitani N, Fujioka K, Murakami K, Seno T, Yamamoto A, Ishino H, Kohno M, Maekawa T, Kawahito Y. Myeloid-derived suppressor cells play crucial roles in the regulation of mouse collagen-induced arthritis. J Immunol. 2013; 191:1073-1081. [PubMed: 23804709]

106. Guan Q, Moreno S, Qing G, Weiss CR, Lu L, Bernstein CN, Warrington RJ, Ma Y, Peng Z. The role and potential therapeutic application of myeloid-derived suppressor cells in TNBS-induced colitis. J Leukoc Biol. 2013; 94:803-811. [PubMed: 23901119]

107. Li Y, Tu Z, Qian S, Fung JJ, Markowitz SD, Kusner LL, Kaminski HJ, Lu L, Lin F. Myeloidderived suppressor cells as a potential therapy for experimental autoimmune myasthenia gravis. J Immunol. 2014; 193:2127-2134. [PubMed: 25057008]

108. Highfill SL, Rodriguez PC, Zhou Q, Goetz CA, Koehn BH, Veenstra R, Taylor PA, PanoskaltsisMortari A, Serody JS, Munn DH, Tolar J, Ochoa AC, Blazar BR. Bone marrow myeloid-derived suppressor cells (MDSCs) inhibit graft-versus-host disease (GVHD) via an arginase-1-dependent mechanism that is up-regulated by interleukin-13. Blood. 2010; 116:5738-5747. [PubMed: 20807889]

109. Yin B, Ma G, Yen CY, Zhou Z, Wang GX, Divino CM, Casares S, Chen SH, Yang WC, Pan PY. Myeloid-derived suppressor cells prevent type 1 diabetes in murine models. J Immunol. 2010; 185:5828-5834. [PubMed: 20956337]

110. Shi M, Shi G, Tang J, Kong D, Bao Y, Xiao B, Zuo C, Wang T, Wang Q, Shen Y, Wang H, Funk $\mathrm{CD}$, Zhou J, Yu Y. Myeloid-derived suppressor cell function is diminished in aspirin-triggered allergic airway hyperresponsiveness in mice. J Allergy Clin Immunol. 2014; 134:1163-1174 e1116. [PubMed: 24948368]

111. Kostlin N, Kugel H, Spring B, Leiber A, Marme A, Henes M, Rieber N, Hartl D, Poets CF, Gille C. Granulocytic myeloid derived suppressor cells expand in human pregnancy and modulate Tcell responses. Eur J Immunol. 2014

112. Nair RR, Sinha P, Khanna A, Singh K. Reduced Myeloid-derived Suppressor Cells in the Blood and Endometrium is Associated with Early Miscarriage. Am J Reprod Immunol. 2015; 73:479486. [PubMed: 25496212]

113. Elahi S, Ertelt JM, Kinder JM, Jiang TT, Zhang X, Xin L, Chaturvedi V, Strong BS, Qualls JE, Steinbrecher KA, Kalfa TA, Shaaban AF, Way SS. Immunosuppressive CD71+ erythroid cells compromise neonatal host defence against infection. Nature. 2013; 504:158-162. [PubMed: 24196717] 


\section{Highlights}

- Ray Owen's studies provided the first mechanistic understanding of tolerance

- Tolerance/immune suppression is a major obstacle for anti-tumor immunity

- Myeloid-derived suppressor cells (MDSC) are potent immune suppressive cells

- Most cancer patients have elevated levels of MDSC

- MDSC are a significant obstacle to anti-tumor immunity 